\title{
External and Internal Debts of Russia
}

\author{
Moiseev V.V. \\ Shukhov Belgorod State Technological University \\ 46 Kostyukova St., Russia, Belgorod, 308012 \\ din_prof@mail.ru
}

Avilova Zh.N.

Belgorod State University

Russia, 308015, Belgorod, Pobedu str, 85

janna-avilova@mail.ru

\author{
Karelina E.A. \\ Moscow State University of Technology \\ «STANKIN»1 Vadkovsky lane, Moscow, 127055, Russia \\ opferpriesterin@mail.ru
}

\author{
Kirova I.V. \\ Moscow Automobile and Road State Technical University \\ (MADI), Russia, Leningradsky Prospect, 64 \\ kirovairina@yandex.ru
}

\begin{abstract}
To implement the new May decrees of the Russian president, a significant breakthrough in the social and economic development of our country will require huge financial resources - more than 35 trillion rubles over the next 6 years. The state budget does not yet have sufficient funds, so the new government intends to attract not only foreign and domestic investments into the economy and social sphere, but also resort to external and internal borrowings.
\end{abstract}

The Russian Federation, one of the richest countries in the world in terms of natural resources, is the largest debtor. Despite the annual production and sale of large volumes of oil, gas, gold, diamonds, non-ferrous metals and other natural resources, our country, due to certain economic policy mistakes, has accumulated external debt in the amount exceeding 700 billion US dollars by the year 2014[1].

Since 2014, thanks to Western sanctions that limit the external borrowing of the Russian Federation, the country's debts have declined significantly. Thus, according to the Central Bank of Russia, the country's foreign debt as of April 1, 2018, i.e. four years later, amounted to 524.9 billion dollars [2], having decreased by $25 \%$.

Public debt is an important component of public finances. Identification of problem aspects of the state's debt policy as well as of directions for its improvement requires a detailed analysis of public debt.

The article analyzes the reasons for the aggregate external debt, the main one of which, according to the authors, is an incorrect economic strategy, a bet on a raw, and not an innovative way of development. It also provides an objective assessment of the state and dynamics of Russia's public debt in recent years.

Keywords: anti-Russian sanctions, external and internal debts, the policy of Russia

\section{INTRODUCTION}

Political leaders of Russia have repeatedly stated that they want to transfer the economy to an innovative development path, but they could not organize work (through financing, tax preferences, close interaction with business, etc.). Instead of building new plants and factories with high-tech equipment, the country's leadership made a bid to build new oil and gas pipelines (North Stream-2, South Stream, a gas pipeline from Siberia to China, etc.). As a result, there appeared dependence on imports of the Russian economy in a number of industries to $80-90 \%$ [3]. Moreover, our government has done everything to ensure that the economy receives a minimum of domestic investment for development. A high interest rate on loans (up to $17 \%$ per annum), the Ministry of Finance and the Central Bank forced Russian banks and corporations to apply for investments abroad. Therefore, on the eve of the introduction of Western sanctions in connection with the events in Ukraine, the major part of Russia's external debt - \$ 547.6 or more than $78 \%$ - accounted for domestic companies' liabilities to external creditors ( $\$ 376.5$ billion) and bank debt (\$171.1 billion) [1].

Over the past seven years, 2011-2017, Russia's gross (consolidated) public debt, according to the Ministry of Finance, has increased 2.7 times, exceeding 11 trillion rubles. At the highest rates, the country's external debt was growing during the period of the crisis in 2014-2015. The main factors contributing to the growth of public debt during this period were the following: a reduction in export earnings against a background of falling prices for oil and gas, other commodities; the growth of defense spending, the development of new types of weapons and military equipment; the need for additional funds to stabilize the economic situation, including in the foreign exchange market; the introduction by Western countries of economic sanctions against Russia, etc. [4].

According to the Ministry of Finance of the Russian Federation, the state external debt (including the obligations of the former USSR, adopted by Russia) for the period 20112016 had increased by $25 \%$ to $\$ 50$ billion, mainly due to an increase in debt on external bonded loans by $17.7 \%$ to $\$ 35.9$ billion, and to a lesser extent due to the growth of state guarantees of Russia in foreign currency in 13 up to $\$ 11.9$ 
billion [5]. The dynamics of Russia's total debt is shown in the following table.

TABLE I. GROWTH OF PUBLIC DEBT IN 2014-2017*

\begin{tabular}{|c|c|c|c|c|}
\hline Indicators / years & $\mathbf{2 0 1 4}$ & $\mathbf{2 0 1 5}$ & $\mathbf{2 0 1 6}$ & $\mathbf{2 0 1 7}$ \\
\hline $\begin{array}{c}\text { Gross national debt } \\
\text { in billion rubles. }\end{array}$ & 7589,3 & 10597,7 & 11120,1 & 11073,5 \\
\hline $\begin{array}{c}\text { Domestic debt in } \\
\text { billion rubles }\end{array}$ & 5722,2 & 7241,2 & 7307,6 & 8003,5 \\
\hline $\begin{array}{c}\text { External debt in } \\
\text { billion rubles }\end{array}$ & 1867,1 & 3356,5 & 3812,5 & 3070,0 \\
\hline
\end{tabular}

From the table it can be seen that the gross public debt in 2014-2017 was growing steadily and, compared with 2014, increased by $45.9 \%$ in 2017 .

The basis of Russia's public debt is domestic debt, the share of which reached $72.3 \%$ by early 2017 . A significant increase in the volume of domestic borrowing, on the one hand, has several advantages over external borrowings. In particular, it is easier for the state to manage such loans, while interest payments on domestic debt contribute to the growth of domestic demand in the commodity market.

On the other hand, the implementation of such a debt policy is largely limited to a higher price of domestic borrowing, the capacity and weakness of the infrastructure of the national financial market. In the event of a significant devaluation of the ruble, domestic borrowings will not be able to fully compensate companies for all their needs for servicing external debt and imports.

We note that the domestic debt of the Russian Federation over the past few years has a clear tendency to increase. In 2014 domestic debt was slightly more than 5.7 trillion rubles, then in just three years it increased by almost $40 \%$ and exceeded 8 trillion rubles. And this is without taking into account the debt to the Russians for the burned savings during the period of hyperinflation during the shock therapy of President Boris Yeltsin, which, according to the Ministry of Finance, is about 11 trillion rubles [6]. According to the federal law "On the restoration and protection of the savings of citizens of the Russian Federation", the deposits of citizens, devalued after 1991, are recognized as the internal duty of the state. If the debt is repaid at a rate that the Ministry of Finance has stated, then the country will return the depreciated savings to citizens only in 80 years. The Russian government, giving priority to the payment of external debts, thereby recognizes that its chief creditor is abroad.

Analyzing the dynamics of the external debt of the Russian Federation in the last four years, it should be noted that the largest volume of external borrowings was at the beginning of 2014 and by 2017 the state external debt, as shown in the table, had increased in ruble terms by $64.4 \%$. It should be noted that the growth of debt in ruble equivalent

* The table was compiled by the authors on the materials of the open press and the data of the Central Bank of Russia. over the years is due to a sharp drop in the ruble's exchange rate against the dollar. In dollar terms, the external debt of the Russian Federation was \$ 51.212 trillion.

Characterizing the structure of the state external debt of Russia, it is necessary to put the debt on bonded loans of the Russian Federation in the first place in terms of borrowing, which accounts for the lion's share $-73.43 \%$. The second place by the share in the total volume of the state external debt of the Russian Federation is occupied by state guarantees in foreign currency $-22.90 \%$. As a rule, state guarantees were provided for projects financed with the participation of international financial organizations, which provided the Russian Federation with mutually beneficial cooperation with such organizations. These actions contributed to the diversification of the economy, the growth of the share of the non-state sector in it, as well as the development of small and medium-sized businesses.

Thus, the volume of the state external debt of the Russian Federation includes:

- the nominal amount of the debt on government securities of the Russian Federation, liabilities in which are expressed in foreign currency;

the amount of the principal debt for loans received by the RF, and the obligations under which are expressed in foreign currency, including targeted foreign loans (borrowings), attracted under state guarantees of the Russian Federation;

- the volume of obligations under the state guarantees of the Russian Federation, expressed in foreign currency.

Determining the optimal size of the external debt of the Russian Federation, its rational use and timely repayment remains one of the most important tasks for the government of any country.

The presence of a large and constantly growing state debt indicates negative trends in the economy and budget policy. In addition, the national debt is capable of increasing inflation and can cause political pressure and so on.

It is worth noting that in an effectively developing and stable economy, the availability of public debt is not treated exclusively as a negative phenomenon. Borrowings at the stage of economic growth testify to the modernization of production, the existence of innovative projects that require serious financial investments not only of private investors, but also of the state.

The presence of a large and constantly growing public debt of the Russian Federation indicates negative trends, such as: withdrawal of funds from the economy for the repayment and servicing of debt obligations, which in turn could be invested in a particular industry; the growth of tax deductions necessary to pay interest on debt, which leads to additional obstacles in the activities of economic entities; public debt can pose a threat to high inflation, and also forms an increase in the debt burden for future generations; can cause political pressure, etc.

At the same time, the authors note that the amount of borrowing without much effort could be reduced by at least $\$$ 100 billion - the value of US debt obligations, in which, 
according to the initiative of AL. Kudrin, a small part of the international reserves of the Russian Federation is kept. Having sold these promissory notes, our state will not only return $\$ 100$ billion to the treasury, protecting ourselves from freezing these foreign assets (and this scenario is not ruled out, taking into account more and more sanctions against Russia on the initiative of US President Donald Trump), but can significantly reduce its external debt, paying off debts with a not very profitable interest. At the same time, the burden on annual servicing of the remaining part of the public debt will be significantly reduced and the upper limit of the state external debt will not be exceeded.

Federal Law No. 362-FZ of 05.12.2017 "On the Federal Budget for 2018 and the Planning Period of 2019 and 2020" sets the upper limit of the state domestic debt of the Russian Federation as of January 1, 2019 in the amount of 10501815935,0 thousand rubles and the upper limit of the state external debt of the Russian Federation as of January 1, 2019 - in the amount of 71.6 billion US dollars or 59.7 billion euros [7].

Under certain circumstances, even an increase in the debt burden, which does not exceed the limit value, while underestimating the possibility of its timely repayment, may lead to an intensification of the crisis phenomena in the country's economy. In this regard, it is necessary not to allow not only the excess of the limit amount of the state external debt of Russia, but also take into account such an indicator as the ratio of the external public debt of Russia and the GDP. This indicator shows a negative trend of an increase from $2.1 \%$ in 2011 to $4.5 \%$ in 2015 .

It should be noted that since the obligations provided by state guarantees are of long-term nature, a significant part of the budget for possible execution (even in the absence of actual payments under state guarantees) is "reserved" and not directed to other priority areas of social and economic development. Despite the fact that additional revenues are provided as a result of the provision of state guarantees, an increase in the amount of state guarantee support inevitably leads to a significant increase in the state budget expenditures (agent fees, administrative expenses related to the provision and further maintenance of each state guarantee).

In recent years, the share of Russia's state guarantees in foreign currency in the amount of state external debt has grown by $21.5 \%$. At the same time, the share of arrears to official bilateral creditors - not members of the Paris Club - by $4.6 \%$, arrears to official multilateral creditors by $6 \%$, and debt on external bond loans - by $4.4 \%$. Debt to official bilateral creditors - members of the Paris Club by early 2015 was repaid.

Management of the external debt of the state can include a sufficiently large set of instruments, including conversion, securitization, debt redemption at a discount, consolidation, refinancing. However, the consequences of using each of them require detailed analysis from the point of view of profitability and elaboration in each individual case. Thus, the main financial mechanism for conversion is the liquidation of a part of external debt requirements by exchanging them for national assets. The transaction is the conversion of debt to private creditors into shares of companies of the debtor country. The advantage of such an operation is that it makes it possible to turn a country's debt into shares by placing foreign direct or portfolio investments in a national enterprise. Securitization means the issue of new securities that confirm the right to property or liabilities of the debtor.

Securitization through Brady-bonds was the most widespread. A buyback of a debt with a discount on the secondary market (buyback) will be beneficial to the borrower when his debts are traded at a big discount, but the debtor country in this case must have significant amounts of gold and foreign exchange reserves or be able to increase them quickly by stimulating the export industries. Active work on the secondary market of debt obligations can lead to a serious saving of budgetary expenses, as there is a decrease in nominal debt and future interest payments. The method of fiscal consolidation involves increasing tax revenues and / or reducing government spending in order to reduce the budget deficit. Some scholars argue that such tough measures are especially effective when the state aims at eliminating the reasons for the budget deficit, that is, too much government spending or, on the contrary, too few and insufficient tax revenues. Adherents of the method of fiscal consolidation also believe that it can lead to an increase in economic growth, increase the confidence of foreign investors in the government and reduce the interest rate charged by investors on government bonds [8].

It seems most effective for regulating the size and structure of Russia's public external borrowings in the medium and long term, a combination of several methods of managing public debt. For example, if the situation in the economy improves, early repurchase of debt or conversion should be used, with less favorable conditions - securitization instruments, exchange of debt for shares of state companies or budget consolidation. At the same time, the state should choose exactly those methods that would least subject economic entities to financial risks, and ideally promote their development on a mutually beneficial basis.

\section{PRoblem STAtement}

In this article, the authors attempted to investigate both the debts of the state, corporations and Russian banks made abroad, and the state's debt obligations to its own population.

Making public borrowings in European countries and other countries of the world, Russia issued securities, attracting creditors with higher interest rates than, for example, the United States of America. On the one hand, this made it possible to quickly obtain the desired loans, and on the other hand, it increased the burden on the state budget for servicing the external debt. Expenses for servicing the public debt of Russia by 2015 reached 650 billion rubles a year, or $0.8 \%$ of the GDP, said Finance Minister A. Siluanov at the parliamentary hearings in the Federation Council [9].

The ratio of Russia's public debt to its GDP may increase to $15.7 \%$ of GDP by the end of 2019 . This is stated in the published paper "The main directions of the debt policy of the 
Ministry of Finance for 2017-2019." At the same time, the share of expenses for servicing the public debt in the total volume of federal budget expenditures by the end of 2017 will be $4.5 \%$, and by the end of 2019 , it will increase to $5.4 \%$, the ministry predicts. [10].

Nevertheless, by early 2017, the total amount of debt burden was still within safe limits - less than $15 \%$ of the GDP, which is moderate by world standards. The Ministry of Finance is planning to receive foreign loans in 2018-2020 through the issuance of sovereign Eurobonds in the amount of $\$ 7$ billion annually and for up to 30 years. During this period, the Ministry of Finance can also exchange old issues of Eurobonds for up to $\$ 4$ billion to reduce the volume of the state external debt of the Russian Federation, reduce the cost of its servicing and reduce the total amount of payments for external loans.

The volume of internal borrowings of the Ministry of Finance in the form of federal loan bonds (OFZ) is planned at 868 billion rubles in 2018, 870 billion rubles - in 2019 and 1.34 trillion rubles in 2020 [11].

For comparison: the national debt of the USA exceeds 21 trillion dollars, reaching a new record by 2018. This is proved by data published by the US Treasury. The major part of public debt is borrowed from private investors - individuals and legal entities, they account for $\$ 15.3$ trillion. One of Trump's election promises was the liquidation of the US public debt. The future president insisted that his economic measures would solve this problem, but during the first year of Trump's presidency, the national debt grew by more than a trillion dollars. During two terms of the US leadership B. Obama, the country's national debt grew by 9.3 trillion dollars [12]. At the same time, the US budget deficit is growing, as in recent years the country's incomes have fallen with the simultaneous growth of expenditures, including military expenditures.

In order to fulfill obligations to creditors and to economic counterparts, the US Treasury has the volume of annual placement by the amount of annual repayment plus the floating volume of the federal budget deficit with a small lag due to cash nuances. Now almost $\$ 8.8$ trillion is placed per year, taking into account bills [13]. And until recently, Russia has been helping the US in financial matters, buying up their government debt obligations in excess of $\$ 103$ billion or more than 6 trillion rubles, withdrawing them from the state budget in accordance with the budget rule.

Budgetary rules were first introduced in 2004, when the Stabilization Fund of the Russian Federation was established. It implies that the additional oil and gas revenues received from the price of oil above the fixed bar will be directed not to expenses, but to reserves. According to Finance Minister A. Siluanov, following the budget rule allows the Russian economy to resist negative externalities, such as instability in world prices for Russian exports and tightening of antiRussian sanctions. "We do not use a higher oil price as a basis for increasing any costs," he said in an interview with CNBC. "All we do is to save this extra income, which goes entirely to the budget. imposing restrictions on Russia, even taking into account the instability, it will be able to withstand any negative effects, "the minister said.

However, let us not agree with the new first vice-premier and head of the Ministry of Finance that "this additional income is entirely directed to the budget." According to the budgetary rule, the so-called super-revenues from oil sales (the base price for Urals oil is now set at \$ 40 per barrel in 2017 prices and subject to an annual indexation of $2 \%$ from 2018) is sent directly to the reserve funds, increasing the so-called "airbag ". Putting off super profits in reserve funds, Russia at the same time gets into new debts and spends more than half a trillion rubles to service external debts annually instead of directing at least some of this money to diversify the economy or reduce poverty, which in the 21 st century exceeds 20000 000 people according to official data. To be more precise, the number of Russian citizens living below the poverty line rose by 2 million in the first quarter of 2017, and now the amount of these people amounts to 22 million. Their share is $15 \%$ of the population. This was stated by the Chairman of the Accounts Chamber, Tatiana Golikova, speaking before the Federation Council. [14].

And we would like to emphasize one more circumstance in this connection. Occupying hundreds of billions of dollars in the foreign market, increasing its arrears from foreign creditors, spending hundreds of billions of rubles on servicing the public debt, increasing the tax burden on the domestic business and ordinary Russians, pondering the question of raising the retirement age, the political leadership of Russia is simultaneously engaged in writing off debts to other countries. According to experts, for the entire post-Soviet period, the Russian Federation "forgave" debts worth over \$ 136 billion ( $\$ 136,607$ billion) or over 8.3 trillion rubles. Details of debt write-offs to debtor countries are reflected in the following table [15].

TABLE 2. DeBt RELIEF By RuSSIA IN 2000-2017.

\begin{tabular}{|l|l|l|}
\hline \multicolumn{1}{|c|}{ Year } & \multicolumn{1}{|c|}{ Country } & \multicolumn{1}{c|}{$\begin{array}{c}\text { Amount of write-off } \\
\text { (\$) }\end{array}$} \\
\hline 2000 & Vietnam & 11 billion \\
\hline 2003 & Iraq & 12 billion \\
\hline 2007 & Algeria & 4,7 billion \\
\hline 2007 & Mongolia & 11,1 billion. \\
\hline 2007 & Afghanistan & 11,1 billion \\
\hline 2008 & Libya & 4,6 billion \\
\hline 2010 & Mongolia & 168 million \\
\hline 2012 & A number of countries in Africa & 20 million \\
\hline 2012 & DPRK & 11 billion. \\
\hline 2012 & Kyrgyzstan & 500 million \\
\hline 2014 & Uzbekistan & 865 million \\
\hline 2014 & Cuba & 29 billion \\
\hline 2015 & A number of countries in Africa & 20 billion \\
\hline 2016 & Mongolia & 174 million \\
\hline 2017 & Ethiopia & 160 million \\
\hline 2017 & Kyrgyzstan & 240 million \\
\hline Total & & 136,607 billion \\
\hline & & \\
\hline
\end{tabular}


From the table it follows that Russia - a generous soul has written off a huge amount of debts to the states of Asia, Africa, as well as Arab countries and some former Soviet republics. Most of the debts written off by Russia are still Soviet debts that were issued on other terms to countries that are often no longer our strategic allies. After the beginning of unrest in this country, which ended with the overthrow of the regime of Muammar Gaddafi, all joint projects were frozen, and the unearned profit of the Russian Federation was about 4 billion dollars [16]. In the case of Bashar Assad's departure, Russia can also lose a major buyer of arms in the person of Syria.

It is possible to understand the leadership of the country in the matter of debt cancellation, but not in all cases. It is not entirely clear, for example, why debts to Iraq, this oilproducing country, which can already successfully pay off petrodollars today, were irrevocably written off. In 2017, Iraq produced and exported 3.27 million barrels of oil per day, and only in February the oil revenues of this former debtor of Russia reached 4.5 billion US dollars. [17] Why, in this case, write off all debts, rather than restructure them? Russian independent Internet publications estimated that if funds that were forgiven to debtors only in 2016-2017 were sent for social needs, then in our country would have been built several hundreds of schools and hospitals, which is really necessary for Russians - but unfortunately, the budget lacks funds for such purposes[18].

The current global practice is that if a state can not repay the debt with money, there is a prospect not to pay it off at all. However, forgiving debt, the creditor can count on the political favor of the debtor, as it happened, for example, with Russia and countries formerly part of the USSR, or for economic benefits, since now the former debtor is ready to let a generous patron on its own market and provide profitable contracts, as was, for example, with the countries of Africa. By forgiving Cuba's debts exceeding \$ 30 billion, Russia could try to sign a contract for the construction of a naval base. With a positive resolution of this issue, the existence of this base would for a long time cool down the aggressive aspirations of the United States towards the island of Freedom. And not only this. However, Russia missed a real opportunity to write off debts. The logic is simple: if you can not get the whole debt, you need to get at least part of it. If you can not get a debt with money, you need to get debt services. If the debtor is hopeless, it is cheaper to forget about this debt rather than to pay for the work of lawyers. In recent years, Russia has partially changed the state policy regarding the cancellation of debts and crediting of petitioners. The country is now forgiving debts and issuing loans in exchange for joint oil and gas projects, as well as contracts for the sale of weapons. So, in 2011, our country allocated a loan to Venezuela for the purchase of Russian weapons. Recently, Bangladesh asked for the same targeted loan. Under this scheme, our weapons will be delivered to Indonesia, Sri Lanka and Jordan [19].

In history there were examples when countries had been remembering for a long time about the generosity manifested at one time and eventually got something in return for it. For example, France did not forget about the debts of tsarist Russia for 79 years and in 1996 received a part of the sum. And the heirs of the British company Lena Goldfields, which was engaged in gold mining in Siberia under a concession, received 65 million dollars, although after the Bolsheviks canceled the treaty in 1929, there were no legal grounds for it [19].

Compared with the public debt of the United States of America, the external debt of the Russian Federation does not look negative. In January 2018, the Central Bank of Russia announced that in 2017 the country's foreign debt amounted to \$ 52.91 billion. Thus, in just one year, 2016, Russia took up \$ 15 billion, increasing its external debt by $2.9 \%$. The Bank of Russia explained this growth by the profitable sale of sovereign debt securities denominated in rubles, which foreign investors had purchased [20].

The increase in this debt was also influenced by the attraction of debt financing from foreign companies that are connected with Russian structures.

The external debt of banks, on the contrary, has decreased to $\$ 104.518$ billion - the minimum level for the last decade [20].

Thus, in general, Russia can be considered a bona fide borrower, who fully and often pays in due time on its debts.

\section{RESEARCH QUESTIONS}

In this study, the authors consider the following questions.

1. To determine the reasons for external borrowings, to show their dynamics in recent years.

2. To analyze the main directions of the state policy of borrowing and servicing external and internal debts in modern conditions.

3. To show the conditions under which the servicing of the national debt can be optimal.

\section{PURPOSE OF STUDY}

The purpose of the study is to study the problems of Russia's internal and external debts and, on this basis, to offer recommendations for their optimization in the conditions of Western sanctions.

\section{RESEARCH METHODS}

When studying the main issues of the topic, the authors use the following methods: 1) an institutional method that allows analyzing the role of the president, government and other authorities in the implementation of the state debt policy; 2) systematic and both structural and functional approaches that allow to form a holistic and objective view of the state of Russia's public debt, to note both positive aspects and existing shortcomings in implementing state policy in this area; 3) the method of comparative analysis was used by the authors to compare the burden of cross-country debt obligations, for example, Russia and the United States; 4) the research also used methods of analysis and synthesis, statistical and other 
methods for determining current trends in the formation of Russia's public debt.

\section{FINDINGS}

1. External public debt is an integral element of the economy of any country. Thus, the state's debt is a very important factor that affects the economic life of the country. Low indicators of public debt favorably distinguish Russia from a significant majority of foreign countries.

2. Limited access to cheap financial resources in foreign financial markets due to Western sanctions forces Russia to borrow at high interest rates; so during 2014-2016, there was a significant increase in the cost of servicing the public external debt.

3. The fall in the country's credit rating, the application of economic sanctions, the weakening of the ruble's exchange rate all contribute to the worsening of borrowing conditions on the world capital market, and also negatively affect the servicing of already existing debt obligations.

4. The practice of recent years has shown that with the introduction of anti-Russian sanctions, bank loans and corporate loans to Russian borrowers are not provided for a long time and are unlikely to be provided in the near future, at least until the abolition of the notorious sanctions.

\section{CONCLUSION}

1. The high growth rates of the public debt, the increase in foreign exchange risks of the public debt, the high cost of attracting new loans and significant amounts of potentially dangerous contingent liabilities of the state actualize the problem of debt sustainability and require a balanced management of Russia's public debt. The system of public debt management refers to interrelated budgetary, financial, accounting, organizational and other measures aimed at effective regulation of the public debt, optimization of its structure and reducing the impact of the debt burden and the associated risks on the economy of the country.

2. Adding the existing vulnerability zones to the impact of the crisis factors that are generated by debt, the state must establish an effective system for monitoring debt security. Weighted management of public finances, the monetary system and the financial sphere is critical for minimizing debt risks and ensuring financial stability in the long term.

3. External borrowing is not a hindrance to the country's social and economic development, provided that the economy is stable, and also that the legislative framework clearly regulates this sphere of relations, as well as that the presence of a state external debt does not negatively affect the international reputation. External borrowing, on the contrary, can contribute to successful modernization economy and society as a whole.

4. Under conditions of macroeconomic instability, it is important to manage the public external debt competently and to apply an effective debt policy taking into account various external and internal factors.

5. The authors believe that for efficient use of raised funds as a result of a state's external and internal borrowing, it would be expedient to direct them primarily to structural reorganization of the economy, its diversification based on the latest achievements of science and modern technologies, including digital technologies and means of switching the national economy of the country from raw materials to an innovative way of development. At the same time, it is necessary to limit the amount of public debt at a level that is safe for the sovereignty of the country.

The time and actions in this area of the new Russian government will show how Russia's external and internal borrowings will develop for the implementation of the May (2018) decree of President Vladimir Putin [21].

\section{References}

[1] Central Bank: Russia's external debt has declined by $13 \%$ since the beginning of the year. - URL: http://www.banki.ru/news/ lenta/?id=8363417 (reference date May 26, 2017).

[2] Central Bank: Russia's external debt since the beginning of the year increased by 6.1 billion dollars. - URL: http://www.banki.ru/ news/lenta/?id=10389233 (reference date May 26, 2018).

[3] V.V. Moiseev, "Actual problems of import subsumption in modern Russia”. Danish scientific journal, vol. 6, pp. 24-29, June 2017 .

[4] A.D. Antonova, E.V. Ponomarenko, "External debt - a threat to the national security of the country?" Bulletin of the Peoples' Friendship University of Russia, series Economics, vol. 4, p. 49-60, May 2016.

[5] Finance of Russia / Federal State Statistics Service. - URL: http://www.gks.ru/wps/wcm/connect/rosstat_main/rosstat/ru/statistics/ publications/catalog/doc_1138717651859 (reference date May 25, 2018).

[6] V.V. Moiseev, "External and internal debts of Russia: state policy". Modern trends in the development of science and technology, vol. 3-8. pp. 12-14, 2016.

[7] Federal Law "On the Federal Budget for 2018 and for the Planning Period 2019 and 2020" of December 5, 2017 No. 362-FZ (last version). URL: http://www.consultant.ru/document/cons_doc_LAW_284360/3 addba9e4c8a682637e7ee2eea8df88e3238952d/ (reference date May 25, 2018).

[8] V.N. Pakhmutov, "On the aspects of management of the external public debt of the Russian Federation in the conditions of economic instability", Scientific journal, vol. 7 (8). p. 53-55, 2016.

[9] A. Siluanov: Russia spends $1 \%$ of GDP spending on public debt. - URL: https://www.vedomosti.ru/economics/news/2015/10/27/614486 -rossiyagosdolga (reference date May 26, 2018).

[10] The state debt of the Russian Federation at the end of 2017 may amount to $14.7 \%$ of GDP. - URL: http://tass.ru/ekonomika/3998827 (reference date May 26, 2018).

[11] The budget of the Russian Federation for 2018 and for the planning period 2019-2020. - URL: http://tass.ru/info/4679765 (reference date May 26, 2018)

[12] The US national debt set an absolute record.- URL: https://lenta.ru/news/2018/03/19/gosdolg/ (reference date May 27, 2018).

[13] Обслуживание госдолга США. - URL: https://spydell. livejournal.com/646143.html (reference date May 27, 2018).

[14] The number of poor in Russia has grown by two million people. - URL: https://lenta.ru/news/2017/06/28/poor/ (reference date May 27, 2018).

[15] Debt relief by Russia. - URL: https://ruxpert.ru/ (reference date May 27, 2018).

[16] Generous soul: Russia is the leader in the number of forgiven debts. URL: http://newsland.com/news/detail/id/1156749/ (reference date May 27, 2018).

[17] Iraq's revenues from oil exports for February 2017 amounted to $\$ 4.5$ billion. - URL: https://neftegaz.ru/news/view/159503-Dohody-Iraka-ot- 
eksporta-nefti-za-fevral-2017-g-sostavili-45-mlrd-doll-SShA (reference date May 27, 2018).

[18] We ourselves are not poor. Russia again forgave billions of debts. What could be done with this money? - URL: https://lenta.ru/ articles/2017/12/25/dolgi/ (reference date May 27, 2018).

[19] Yu. Zabavina, A generous soul. - URL: https://newizv. ru/news/economy/08-04-2013/180701-shedraja-dusha (reference date May 27, 2018).
[20] Russia's external debt in 2017 increased to \$ 529.1 billion. - URL: https://www.kommersant.ru/doc/3526345 (reference date May 27, 2018).

[21] The President signed the Decree "On national goals and strategic tasks of the development of the Russian Federation for the period until 2024" - URL: http://kremlin.ru/acts/news/57425 (reference date May 28, 2018). 